\title{
New evidences on the presence of Aphelocheirus aestivalis in the Iberian Peninsula, its ecology and description of two northeastern Iberian populations
}

\author{
Marcos Roca-Cusachs ${ }^{1}$, Marta Goula ${ }^{1, *}$, Cesc Múrria $^{1,2}$, Pau Fortuño ${ }^{2}$, Laia Jiménez ${ }^{3}$, Núria \\ Sellarès ${ }^{3}$, Marc Ordeix ${ }^{3}$ and Narcís Prat ${ }^{2}$
}

${ }^{1}$ Departament de Biologia Evolutiva, Ecologia i Ciències Ambientals and IRBio, Faculty of Biology, University of Barcelona. Avda. Diagonal 643. 08028 Barcelona, Catalonia, Spain.

2 FEHM, Ecology and Management research group. Departament de Biologia Evolutiva, Ecologia i Ciències Ambientals. Faculty of Biology, University of Barcelona. Avda. Diagonal 643. 08028 Barcelona, Catalonia, Spain. ${ }^{3}$ CERM, Center for the Study of Mediterranean Rivers, University of Vic - Central University of Catalonia. Ter River Museum, Passeig del Ter 2, 08560 Manlleu, Catalonia, Spain.

* Corresponding author: mgoula@ub.edu

Received: $17 / 05 / 17 \quad$ Accepted: $15 / 07 / 19$

\begin{abstract}
New evidences on the presence of Aphelocheirus aestivalis in the Iberian Peninsula, its ecology and description of two northeastern Iberian populations

The waterbug Aphelocheirus aestivalis is herein recorded for the first time in Northeastern Iberian Peninsula, constituting the first citation of the family Aphelocheiridae in the region. Yet, later on in 1989, the description of three new endemic Iberian species belonging to Aphelocheirus implied the assumption that A. aestivalis was absent in the Iberian Peninsula. Here, we show strong evidences of the presence of this species by the collection of individuals in two isolated stream reaches located $36 \mathrm{~km}$ apart, in the two Mediterranean rivers Llobregat and Ter. The Iberian specimens studied showed slight differentiation from other European specimens in the structures of male internal genital. Photographs of the habitus of the male and female are provided. More than 25 years of study of these rivers show that Aphelocheirus sp. is confined solely to a short stretch in both rivers. Our study thus suggests that the distribution of $A$. aestivalis in the Iberian Peninsula should be revised and further investigated, and warns of urgent measures to improve, or at least preserve, the habitat and the hydrological conditions rivers Llobregat and Ter to protect the species.
\end{abstract}

Key words: water bugs, faunistics, Iberian fauna, stream ecology, Mediterranean streams, aquatic macroinvertebrates

\section{RESUMEN}

Nuevas evidencias de la presencia de Aphelocheirus aestivalis en la Península Ibérica, su ecologia y descripción de las poblaciones del noreste ibérico

La familia Aphelocheiridae se registra por primera vez en el noreste de la Peninsula Ibérica tras la captura de Aphelocheirus aestivalis. Tras la descripción de tres especies de Aphelocheirus endémicas de la Península Ibérica, se descartó que A. aestivalis formara parte de la fauna ibérica. Nuestro hallazgo pone de manifiesto lo contrario, sugiriendo que la distribución de A. aestivalis en la Península Ibérica debería revisarse. El material estudiado presenta ligeras diferencias con respecto a ejemplares de otras localidades europeas en las estructuras genitales internas masculinas. Se proporcionan fotografias del hábito del macho y de la hembra. Los ejemplares fueron encontrados en dos localidades de los ríos Llobregat y Ter, distantes $36 \mathrm{~km}$ entre sí. Más de 25 años de estudio en ambas cuencas apuntan que Aphelocheirus sp. se halla confinada a un corto trecho de esos ríos, y por tanto se requieren medidas urgentes para preservar el hábitat y las condiciones hidrológicas con el fin de proteger la especie.

Palabras clave: chinches acuáticos, faunística, fauna ibérica, ecología fluvial, rios mediterráneos, macroinvertebrados acuáticos 


\section{INTRODUCTION}

The family Aphelocheiridae is distributed in the Eastern Hemisphere (Polhemus \& Polhemus, 2008) and includes a single genus, Aphelocheirus Westwood, 1833. This genus has around 100 species (Xie \& Liu, 2014), 30 of which in the Palearctic Region (Kanyukova, 1995; Aukema et al., 2013). Aphelocheirus aestivalis (Fabricius, 1794 ) is the most common and widely distributed species across Europe. In the Iberian Peninsula, A. aestivalis was reported several times during the 20th century (Lindberg, 1929; Seabra, 1926, 1939, 1941; Pardo, 1933; Gómez Menor, 1956; Serrao \& Azevedo, 1970; Nieser, 1978; Baena, 1980; Fernández, 1982; Murillo, 1985; Lucas, 1988; Grijalbo, 1991; López et al., 1995; Casado et al., 1990; López, 1998; Millán et al., 2002; Sánchez-Hernández, 2011), and was included in the current checklist (Nieser \& Montes, 1984), catalogue (González, com. pers. in Baena \& Vázquez, 1986) and keys (Nieser et al., 1994; the authors suggest confirmation for $A$. aestivalis, a species included in the key). However, in 1989 the three Iberian endemic Aphelocheirus species Aphelocheirus murcius Nieser \& Millán, 1989, Aphelocheirus occidentalis Nieser \& Millán, 1989 were described, and an innominate Aphelocheirus sp. considered (Carbonell et al., 2011) which apparently replaced the original records of A. aestivalis. Thus, since 1989 the presence of $A$. aestivalis has been questioned (Nieser \& Millán, 1989, Nieser et al., 1994) or explicitly rejected (Carbonell \& Millán, 2010; Carbonell et al., 2011; Millán et al., 2016) in the Iberian Peninsula. The main criticism on the presence of $A$. aestivalis in the Iberian Peninsula was that ancient citations were based on poorly studied specimens, which in fact should belong to any of the three Iberian endemic species (Nieser \& Millán, 1989).

Although several studies of Aphelocheirus were published dealing with its distribution (Bracken, 1974; Zivic et al., 2007), behavior (Lemb \& Maier, 1996), life cycle (Papáček, 2012; Papáček \& Soldán, 2008) or physiology (Thorpe \& Crisp, 1947a, 1947b, 1947c; Messner et al., 1986), many aspects of its ecology and conservation biology are still to be addressed. Species belonging the genus Aphelocheirus inhabit lakes and the upper and mid sections of streams with unperturbed environmental conditions, making them good indicators of water quality and ecological status (De Brabander et al., 1992; Pardo et al., 2014). Moreover, Aphelocheirus spp. may consistently contribute to food webs as food resource for freshwater fishes (Sánchez-Hernández \& Cobo, 2011). Unfortunately, the preferred habitat of Aphelocheirus species are at conservation risk mostly by anthropogenic reasons such as water pollution, hydromorphological changes, habitat fragmentation and water over-extraction (Papáček, 2012; Stoianova et al., 2018), which are even more critical in Mediterranean streams submitted to an important water stress in summer (Filipe et al., 2013). While streams located in protected areas are still in good biological condition, the middle and lowland section of most of the Mediterranean streams have been heavily modified and receive untreated wastewater (Prat \& Munné, 2000), highly impeding the presence of many macroinvertebrate species, including Aphelocheirus bugs (Fortuño et al., 2018). Moreover, it is accepted that $A$. aestivalis disperses mainly through the watercourses (Papáček, 2012). In fact, only micropterous individuals of Iberian Aphelocheirus species have been captured (Carbonell \& Millán, 2010), and therefore their poor dispersal abilities could increase their vulnerability in case of habitat loss. As a result, Carbonell \& Millán (2010) included all the Iberian Aphelocheirus spp. in the Spanish Red List as Vulnerable taxa (IUCN criteria). Similarly, $A$. aestivalis is included in the Red List of several European countries, for instance in Flanders (Maes et al., 2019), or the Check Republic (Papáček, 2012).

Rivers in Catalonia are in general relatively short, narrow and highly menaced to drought during hot Mediterranean summers (Múrria et al., 2010). Many of those streams were highly transformed since the end of $19^{\text {th }}$ century during the industrialization process and more recently by urbanization. Llobregat and Ter rivers basins are paradigmatic examples. At the end of $19^{\text {th }}$ century, a system of weirs diverting water through canals to textile-mills, and throwing it back to the river and soon after diverted again to the follow- 
ing textile-mill, resulted in highly altered water flow. In addition to hydrological issues, treated or untreated sewage waters from domestic and industrial uses decreased the water quality, which has been recovered during the last two decades when waste water treatment plants have been built. Since half of the 20th century, the textile mills were transformed into hydroelectric power stations, and water diversion continued until present with variable but severe effects on freshwater macroinvertebrate communities (Prat \& Rieradevall, 2006). Nevertheless, the residual flows below the weirs may maintain acceptable-good hydrological and environmental conditions that should be considered as refugees for biota. In order to evaluate the ecological quality of Llobregat river, the first ecological study along the river was performed in 1979, but since 1994 the middle river sections of the Llobregat and Ter rivers have been routinely biomonitored as part of the program called "Qualitat Ecològica dels Rius de la Província de Barcelona" (www.ub.edu/ barcelonarius). As a result, more than 50 sites located along the $208 \mathrm{~km}$ of the Ter and $175 \mathrm{~km}$ of the Llobregat were sampled following the same protocol (Prat et al., 2012).

Here, we examined the specimens collected during the project "Qualitat Ecològica dels Rius de la Província de Barcelona". We report the family Aphelocheiridae in the north-eastern Iberian Peninsula for the first time, and the presence of $A$. aestivalis that was in the last decades considered absent from the Iberian Peninsula. We include morphological and genital descriptions, illustrations of its habitus and an ecological characterization of its habitat.

\section{MATERIALS AND METHODS}

\section{Field sampling and habitat characterization}

The project "Qualitat Ecològica dels Rius de la Província de Barcelona" provides a long-term species record series with samples collected regularly (spring and summer) from 1994 until present. Additionally, samples collected in the Llobregat river during 1979-80 were also available. In this project, the specimens of Aphelocheirus were collected using a circular hand net of

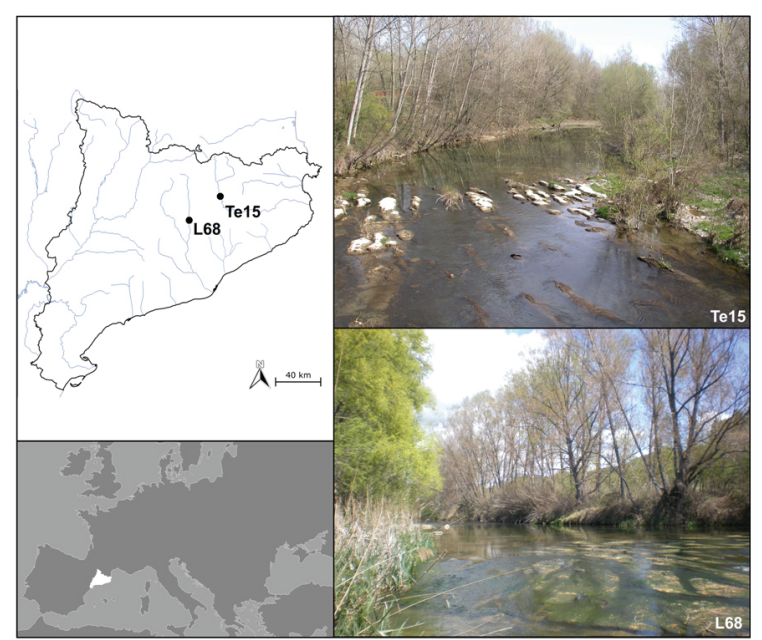

Figure 1. Location of Catalonia in Western Europe. Geographical distribution and habitat of sites L68 and Te15 where Aphelocheirus aestivalis was found (North-East Iberian Peninsula). Localización de Cataluña en Europa occidental. Distribución geográfica y hábitat de las localidades L68 y Te15 donde Aphelocheirus aestivalis ha sido hallada (Noroeste Peninsular).

$250 \mu \mathrm{m}$ mesh net and were usually preserved in $10 \%$ formaldehyde solution, as required for the current monitoring protocol (Prat et al., 2012). Aphelocheirus was found only in two river reaches that were located in the middle sections of the Llobregat and Ter rivers (L68, Balsareny; and Te15, Torelló; Fig. 1). In their middle sections, these two rivers are separated by low-elevation topographic barriers and thus could constitute a contact zone between them in case of overflow.

In order to determine the ecological conditions of these river reaches, we analyzed water temperature, electrical conductivity, oxygen (concentration and percentage of saturation) and $\mathrm{pH}$ were determined using a multi-parametric digital probe YSI ${ }^{\circledR}$ Pro Plus. Water samples were filtered through glass fiber filters (GF/F; Whatman, Maidstone, UK), transported to the laboratory on ice, and finally frozen for subsequent analysis. Major anions (chloride, sulfate, nitrite and nitrate) were analyzed by high-pressure liquid chromatography and ammonium and soluble reactive phosphorus concentrations were estimated using standard colorimetric methods. We also calculated the river flow (1/s) measuring the river section (width $\mathrm{x}$ depth) and current velocity of water with a digital 
anemometer Schiltknecht ${ }^{\circledR}$ MiniAir2. Additionally, we used the Fluvial Habitat Index (IHF, Pardo et al., 2004) to determine the physical habitat structure, and the Quality of Riparian Forest Index (QBR, Munné et al., 2003) to characterize the riparian habitat.

\section{Specimens study}

In the laboratory, specimens were cleansed with distilled water prior to dry mounting. All adults were glued on $10 \times 21 \mathrm{~mm}$ cardboard mounting cards (dry mounted) and individually pinned, whereas juveniles were piled up under the same needle. Individuals were examined under a Leica MZ160A (10-115X) and Leica MZ 125 binocular stereoscopes. Specimens fixed in formaldehyde (specified in the data label) did not show the typical colouration of the species, because of fixation. Male genitalia were dissected and genitalic structures were glued on the same card as the specimen. In all adult specimens, biometric characters useful in taxonomy (i.e., total length, total width, leg segment lengths) were measured. Photographs of the habitus and male genitalia were taken using a Nikon DXM1200 and LEICA DFC 450 cameras attached to the stereoscope. A series of 10 to 30 photographs were combined and image processed with the Helicon Focus 6.2.2. image-stacking and processed using Photoshop CS5.

The acronyms of collections where specimens are deposited are as follows: CRBA, Centre de Recursos de Biodiversitat Animal, Universitat de Barcelona, Spain; JRC, Jordi Ribes Collection (deposited in CRBA); MGC, Marta Goula Collection; MRCC, Marcos Roca-Cusachs Collection.

\section{RESULTS}

\section{Material studied}

In the list below, doble dash (//) separate the contents of different labels, and sample dash (/) indicates lines within the same label. All together 33 specimens were considered.

(1M, CRBA) Riu Llobregat, Balsareny, / Catalunya, Península Ibèrica / 41.85943 N, 1.87998 E / 11th May 2016 / M. Roca-Cusachs,
P. Fortuño \& N. Prat leg. // MRCAPHEL04 // Aphelocheirus aestivalis // deposited at Centre de Recursos de la Biodiversitat Animal with code: CRBA-54282. (1F, MRCC); Riu Llobregat, Balsareny, / Catalunya, Península Ibèrica. / $41.85943 \mathrm{~N}, 1.87998 \mathrm{E} / 11^{\text {th }}$ May 2016. / M. Roca-Cusachs, P. Fortuño \& N. Prat leg. // MRCAPHEL01; // Aphelocheirus aestivalis (1F, MRCC): same locality / 11th May 2016. / M. Roca-Cusachs, P. Fortuño \& N. Prat leg. // MRCAPHEL02; (1F, MRCC): same locality / $11^{\text {th }}$ May 2016. / M. Roca-Cusachs, P. Fortuño \& N. Prat leg. // MRCAPHEL03; (1M, MGC): same locality / 13th April 2010 / P. Fortuño \& N. Prat leg. // fixed in formaldehide // Aphelocheirus aestivalis $(1 \mathrm{~F}, \mathrm{CRBA})$ : same locality / $13^{\text {th }}$ April 2010. / P. Fortuño \& N. Prat leg. // fixed in formaldehide // Aphelocheirus aestivalis //deposited with code CRBA-54283; (1F, MGC): same locality / 10th June 2009. / P. Fortuño \& N. Prat leg. // fixed in formaldehide // Aphelocheirus aestivalis; (1F, MRCC): same locality / 10th June 2009. / P. Fortuño \& N. Prat leg. // fixed in formaldehide // Aphelocheirus aestivalis; (1M, MRCC): same locality / $10^{\text {th }}$ June 2009. / P. Fortuño \& N. Prat leg. // fixed in formaldehide; (1F, CRBA): same locality / 7th May 2008. / P. Fortuño \& N. Prat leg. // fixed in formaldehide // deposited with code CRBA-54284; (1M, MRCC): Riu Ter, Torelló, Catalunya, / Península Ibèrica. / $41.01196 \mathrm{~N}, 2.25640$ E. / 30th May 2016. // MRCAPHEL05 // Aphelocheirus aestivalis; (1 juvenile, CRBA): Riu Llobregat, Balsareny, / Catalunya, Península Ibèrica. / 41.85943 N, 1.87998 E. / 25th April 2013. / P. Fortuño \& N. Prat leg. // fixed in formaldehide // Aphelocheirus aestivalis // in etOH $70 \%$, deposited with code CRBA-54290; (4 juveniles, CRBA): same locality / 18th July 2012. / P. Fortuño \& N. Prat leg. // fixed in formaldehide // Aphelocheirus aestivalis // dry mounted, deposited with code CRBA-54287; (4 juveniles, CRBA): same locality / 24th April 2012. / P. Fortuño \& N. Prat leg. // fixed in formaldehide // Aphelocheirus aestivalis // dry mounted, deposited with code CRBA-54286; (2 juveniles, CRBA): same locality / 27th July 2011. / P. Fortuño \& N. Prat leg. // fixed in formaldehide // Aphelocheirus aestivalis // in etOH $70 \%$, de- 
posited with code CRBA-54288; (1 juvenile, CRBA): same locality / 3rd May 2011. / P. Fortuño \& N. Prat leg. // fixed in formaldehide // Aphelocheirus aestivalis // in etOH $70 \%$, deposited with code CRBA-54289; (2 juveniles, CRBA): same locality / 10 th June 2009. / P. Fortuño \& N. Prat leg. // fixed in formaldehide // Aphelocheirus aestivalis // dry mounted, deposited with code CRBA-54285; ( 3 juvenile, CRBA):

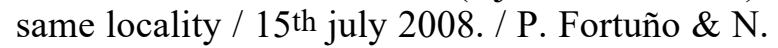
Prat leg. // fixed in formaldehide // Aphelocheirus aestivalis // in etOH $70 \%$, deposited with code CRBA-54292; (2 juvenile, CRBA): same locality / 7th May 2008. / P. Fortuño \& N. Prat leg. // fixed in formaldehide // Aphelocheirus aestivalis // in etOH $70 \%$, deposited with code CRBA-54291; (1M, CRBA): Kl. Schierensee / Umg. Kiel / H. H. Weber leg./ 17.10.47 // Aphelocheirus / aestivalis F. / H. H. Weber det. 195. From JRC; (1M, CRBA): Silesia / Lucina / 20.VII.1952 // Aphelocheirus / aestivalis F.(F.) / Štusák det. 68. From JRC;

Specimens with code CRBA are deposited at the Centre de Recerca de Biodiversitat Animal (CRBA) at the Faculty of Biology, University of Barcelona with collection codes shown on the data label information mentioned herein.

\section{Description of $A$. aestivalis from Northeast Iberian Peninsula}

A detailed description of $A$. aestivalis micropterous specimens collected is given, remarking the characters which are slightly different to the specimens revised from out of the Iberian Peninsula. In general, the variation of most features between Iberian and non-Iberian specimens is very weak. Specimens fixed in formaldehyde lost the typical colouration of the species, as may be seen in Figures $2 \mathrm{f}$ and $2 \mathrm{~g}$, but the morphology was unaltered. Measures are given in $\mathrm{mm}$.

General habitus. Micropterous. Length, 9.6 (9.1-10). Width, 7.1 (6.8-7.5). Overall appearance ovate (Fig. 2), flattened. Dorsum mostly dark brown with contrasting yellow head, legs, margins of thorax, abdomen and two light markings on pronotum and abdomen. Ventral surface brownish.

Head. Yellow. Head punctuate, punctuation finer in the middle of head; greatest head width at anterolateral corners of eyes, 2.2 (2.1-2.2); with sparse, short setae surrounding eyes. Head length 1.6 (1.1-1.8). Eyes black, semi-rectangular, anteriorly divergent, external margins gently sinuate and slightly pointed outwards near the anterior end. Interocular distance between anteromedial corners of eyes 1.7 (1.6-1.7), between posteromedial corners of eyes 1.2 (1.1-1.3). Eye length 0.9 (0.8-0.9). Eye width $0.5(0.4-0.5)$. Venter concolour with dorsal colouration, and covered with sparse, thin, short setae. Antennae pale, 4-segmented. Length of antennal segment: 5-7-14-17. Labrum evenly rounded anteriorly. Rostrum concolour with head, not surpassing middle of mesocoxae. Four visible rostral segments, total length: 3.7 (3.3-3.7).

Pronotum. General colour brown. Yellow at lateral band and along two markings at center; very finely tuberculate; sparse, yellowish very short shiny setae; posterior margin slightly concave, nearly straight, sometimes narrowly yellow coloured; pronotum width 5.2 (4.9-5.2), length 1.3 (1.1-1.3). Prosternum carinate at midline. Propleuron brown; posteromedial corner sharply acuminate, directed ventromedially. Mesosternum light brown, sparsely covered with small setae. Mesosternum with small, but well-developed, mid-ventral process.

Scutellum. Triangular; brown with yellowish apex; very finely tuberculate; sparse, yellowish very short shiny setae; anterior margin straight, posterior apex slightly rounded; length 0.9 (0.9-1.1) mm, width 2.9 (2.5-2.9).

Hemelytra. Very finely granulate with fine longitudinal markings, brown, lighter at anterolateral corners and posterior margin; anterolateral corners produced in a semi right angle; rounded posteriorly; slightly separated medially; distance of separation $0.8(0.4-0.8)$; hemelytra width 6 (5.5-6), length 2.1 (1.8-2.1).

Legs. Yellow, legs segments rod-like, or somewhat angular. Mesal surface of all coxae and trochanters with short shiny setae. Coxae with dense row of stout elongate setae on mesoapical margin. Claws concolour with legs, gently curved, tips darker. Profemurs with anterolateral surface covered in a dense, short, shiny pilosity. Lengths of profemur, protibia, protarsomeres 
1-3: $2.3,1.9,0.1,0.25,0.4$. Mesofemora and mesotibia covered in thin setae and short thin spines. Mesotibia with stout peg like spines on apex. Lengths of mesofemur, mesotibia, mesotarsomeres 1-3: 2.4, 1.9, 0.1, 0.3, 0.4. Metafemora with scattered, stout setae throughout. Metatibia and metatarsus with dense row of swimming hairs continuously distributed and short scattered spines; metatibia and metatarsus apex with circlet of stout spines, swimming hairs lighter coloured
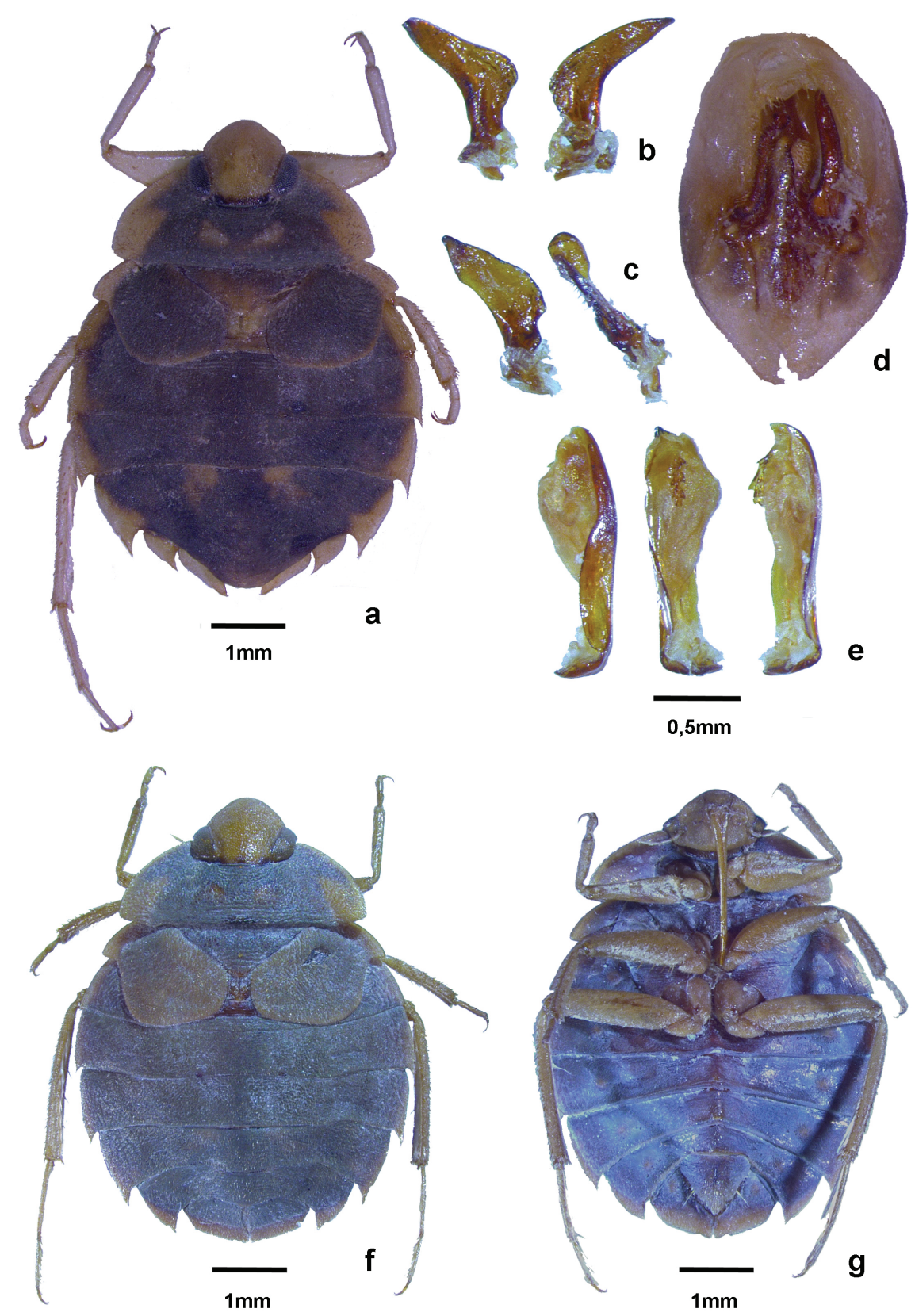

Figure 2. Aphelocheirus aestivalis a) Male dorsal habitus; b) Right paramere; c) Left paramere; d) Genital capsule; e) Aedeagus; f) Female dorsal habitus; g) Female ventral habitus. Aphelocheirus aestivalis a) Hábito dorsal del macho; b) Parámero derecho; c) Parámero izquierdo; d) Cápsula genital; e) Edeago; f) Hábito dorsal de la hembra; g) Hábito ventral de la hembra. 
than legs. Metatarsomer1 inconspicuous. Lengths of metafemur, metatibia, metatarsomeres 2-3: 3.1, 3.5, 1.6, 0.9 .

Abdomen. Brown with yellowish margins, extended in posterolateral acute processes in all visible segments. Tergites very finely granulate, with very short, yellowish shiny setae scattered throughout. Lateral margins narrowly glabrous. Posterolateral angle of segment II very slightly acuminate; III-V acuminate with progressively larger, broadly triangular spiny process; VI-VII produced and pointed with scattered recumbent setae. Male abdominal tergite $\mathrm{V}$ large, covering most of tergites VI to IX, segment IX reduced. Female abdominal tergites $\mathrm{V}$ and VI normal shaped, VII divided in two valves with two mediocaudal points. Sterna generally pruinose throughout. Spiracular rosettes on sterna II-VII reduced and 3/4 distance from midline to lateral margin. Hydrostatic organ on abdominal sternite II large, ovate, laterally compressed, length 0.5 , with semi rounded borders.

Genitalia. Male genital capsule light yellowish, apex broadly pointed; heel of left paramere arrow shaped, paramere thickened at center, and subtly constraint, somewhat pointed at apex; right paramere elongated, with pointed apex and rounded heel, parameres lacking a thick fringe of hairs; aedeagus with 3 pairs of robust spines in apical section of interior margin and ending in a prominent fang shape process. Female operculum pointed shaped with lateral hair tufts consisting in a brush of long, dense hairs orientated backwards. Apical pilosity not developed into a real tuft.

Ecology. The sites where specimens of $A$. aestivalis were found belong to water bodies typified as "Mediterranean rivers with High Flow" (ACA, 2010). The reaches where the specimens were collected are relatively wide (up to 50 meters) with a substrate formed by large rocks, stones, boulders, gravel and sand, which is not always the common niche occupied by $A$. aestivalis (Giordano, 2018). The altitude of the sites is, respectively, 285 (L68) and 483 (T15) $\mathrm{m}$ a.s.l. The water flows seasonally with low discharge in summers and maximum in spring and autumn with an annual average of 7.07 $\mathrm{m}^{3 / \mathrm{s}}$ (L68) and 15.18 (T15) $\mathrm{m}^{3 / \mathrm{s}}$ (ACA, 2000). Available data of the biomonitoring program since 2002 show conductivity ranging between 250 and
$1000 \mu \mathrm{S} / \mathrm{cm}$ and average values of nitrate of 0.98 (L68) and 0.69 (T15) $\mathrm{mg} \mathrm{N}-\mathrm{NO}_{3} / \mathrm{L}$, phosphorous of 0.07 (L68) and 0.04 (T15) $\mathrm{mg} \mathrm{P}_{-} \mathrm{PO}_{4}{ }^{3-/ \mathrm{L}}$, temperature of 14.8 (L68) and 18.1 (T15) ${ }^{\circ} \mathrm{C}$ and $\mathrm{pH}$ of 8.28 (L68) and 8.35 (T15). The presence of macrophytes was common, mainly Potamogeton pectinatus (L.) Böerner in the bed of the river that can develop into large mats, due to moderate levels of phosphorous content in the waters (some eutrophication), and Phragmites australis (Cav.) Trin. ex Steud. and Typha sp. on the banks. Finally, according to the Water Framework Directive (WFD), the ecological status since 2002 ranged between moderate and good, but occasionally very good, as riparian forest quality at both sites is moderate and the biological indices ranged between good and very-good (Prat et al., 2016) (Fig. 1).

\section{DISCUSSION AND CONCLUSION}

The $A$. aestivalis specimens found at the Ter and Llobregat are the first record of the family Aphelocheiridae in Catalonia (Goula et al., 2010; Ribes et al., 2004; 2008), and more extensively in Northeastern Iberian Peninsula. Moreover, this record reconfirms the species in the Iberian fauna (Carbonell \& Millán, 2010; Carbonell et al., 2011; Millán et al., 2016). According to Millán and collaborators (2016), the only reliable characters are head silhouette, spiny processes in the lateral margin of abdominal segments, and male genitalia. Following Carbonell et al. (2011), Papáček (2012) and Millán et al. (2016), the males of $A$. aestivalis collected in the Northeastern Iberian Peninsula have clear distinctive characters in the genitalia. The left paramere is lanceolate at the apex (truncate or rounded in the other species), its body is approximately as long as base (body is longer than base in the other western Palaearctic species), right paramere shows a heel (as in European $A$. aestivalis and $A$. murcius), its interior profile is angulated (curved in these latter two species), and the aedeagus is provided with lateral spines in apical part (as found for the Iberian $A$. murcius and Aphelocheirus sp., and the European A. aestivalis), ending in a prominent fang shape process (exclusive character for the Northeastern Iberian Peninsula populations). Thus, we believe the Northeastern Iberian Peninsula specimens 
belong to $A$. aestivalis, and differences in male genitalia have to be interpreted as variations within the species (A. Millán com. pers.).

Findings of $A$. aestivalis in Northeastern Iberian Peninsula indicate the need for a rigorous revision of the taxonomy of the genus Aphelocheirus in the Iberian Peninsula and its current distribution. The controversy is distinguishing the records attributed to $A$. murcius and A. occidentalis, which progressively enlarge their distribution as more studies have been published (i.e., Miguélez \& Valladares, 2010) from record of $A$. aestivalis, or vice verasa. For instance, specimens captured in the rivers Perales and Manzaneres (López et al., 1995) and Lozoya (Casado et al., 1990) in the Madrid province were attributed to $A$. aestivalis, but this assignation have to be rechecked because Madrid is in the joint point of the distribution range of $A$. murcius and A. occidentalis. Similarly, A. aestivalis has recently been reported in the province of Ávila in the frame of a macroinvertebrate study (Sánchez-Fernández, 2011), largely after $A$. occidentalis was stated. A. occidentalis is morphologically similar to $A$. aestivalis, thus adding more ambiguity on the distribution of Aphelocheirus species in the Iberian fauna. The intraspecific variability in morphology is not exclusive for the Iberian specimens, A. aestivalis has been largely reported across Europe and an extensive review revealed morphological divergences across its distribution range (Papáček, 2011).

In the Llobregat and Ter rivers, more than 25 years of continuous monitoring are available for 52 sites across the entire basins (Prat \& Rieradevall, 2006). During these years, Aphelocheirus specimens were collected almost every year only in one isolated site in each basin categorized in "good ecological status", which indicates isolated but stable populations. Presumably, those specimens could belong to A. aestivalis, but unfortunately, the majority of those samples were lost. These sites are among the few reaches in the Llobregat and Ter rivers where the water flow has not been or is scarcely diverted for hydroelectrical purposes and did not receive direct inputs from sewage water. Therefore, the minimum annual water flow $\left(>1 \mathrm{~m}^{3 / \mathrm{s}}\right)$ at this site is guaranteed and provides enough water renewal to maintain the oxygen levels close to saturation at the substrate, which is important for cutaneous and plastron respiration of Aphelocheirus (Thorpe, 1950). On the contrary, most of the reaches upstream and downstream from the localities where $A$. aestivalis is found are unsuitable as most of the water flow is diverted out from the river, a fact that is especially critical during dry summers in Mediterranean streams (Gasith \& Resh, 1999; Filipe et al., 2013), with water flow limited to $100 \mathrm{l} / \mathrm{s}$. The low water flow in summer produces water stagnation, which together with the high temperature, decrease the oxygen concentration in water, leading to sulphate reduction to sulphide under large rocks, and this effect is increased when reaches received direct inputs from treated (now) or untreated (in the past) sewage water. As a result, $A$. aestivalis cannot refuge under the stones and boulders during daytime. Specially critical is species conservation in the Llobregat river because downstream from the locality the physico-chemical condition of water is unsuitable for $A$. aestivalis requirements due to the runoff from huge salt mines activity, resulting in a strong increase of conductivity $(\sim 2200 \mu \mathrm{S} / \mathrm{cm})$, and other water pollutants (Cañedo-Argüelles et al., 2015). Moreover, the upstream La Baells reservoir $(102 \mathrm{~m}$. high dam, $11 \mathrm{~km}$ of length and an average depth of $35 \mathrm{~m}$.) releases relatively cold water from near the bottom of the reservoir that may limit upstream dispersion of $A$. aestivalis in summer. Temperature and $\mathrm{pH}$ conditions in the localities where $A$. aestivalis was collected are within the range already known in other localities, but the species can accept more acid and cold conditions (Papáček, 2012; Stoianova et al., 2018; Giordano, 2018). In any case, the persistent and intensive monitoring of both Ter and Llobregat rivers suggests that the narrow distribution of Aphelocheirus is not associated directly to low sampling intensity, instead is likely the species response to unappropriated water environmental conditions.

In conclusion, the specimens of $A$. aestivalis were found in isolated, preserved and unique reaches in the highly modified Llobregat and Ter rivers basins. The strong habitat specificity of the species and its highly limited dispersal abilities 
explain its fragmented distribution, which leads to the risk of population disappearance. Under those circumstances, A. aestivalis should be considered together with the other Iberian Aphelocheirus endemics to be added in the red list of threatened invertebrates. Moreover, Mediterranean rivers are some of the most threatened aquatic ecosystems worldwide (Abellán et al., 2005; Filipe et al., 2013; Sánchez-Fernández et $a l ., 2008)$ because of the ongoing urban, industrial and agricultural pressures that critically reduce their water flow, biological condition and ecological quality, thus the localities where the species has been found are under threat. Although it has been proved that $A$. aestivalis responds to habitat restoration by means of adding wood debris (Brugmans et al., 2015), the protection of the fragile ecosystems of the genus Aphelocheirus in the Iberian Peninsula is compulsory by maintaining the water flow in summer at least at the same level as we have today. On the other hand, the high score of Aphelocheiridae (10) attributed by the Biological Monitoring Working Party (BMWP) (Bartram \& Balance, 1996) does highlight its great sensitivity and the need of preserving the few habitats and niches were the species was found.

\section{ACKNOWLEDGEMENTS}

We would like to thank all researchers that collaborated in the biomonitoring program "Qualitat Ecològica dels Rius de la Província de Barcelona" since 1994, and the Diputació de Barcelona for funding the program through several projects (ECOBILL, ECOSTRIMED and CARIMED). To A. Millán for valuable comments, and together with J.A. Carbonell for facilitating all the bibliography requested and their helpful advice. To R. Sites (University of Missouri) for his critical revision of the manuscript that improved the final version. To M.Á. Vázquez and F. Faracci for critical reading of a previous manuscript.

\section{REFERENCES}

ABELLÁN, P., D. SÁNCHEZ-FERNÁNDEZ, J. VELASCO \& A. MILLÁN. 2005. Assessing conservation priorities for insects: status of water beetles in southeast Spain. Biological Conservation, 121: 79-90.

ACA (AGĖNCIA CATALANA DE L'AIGUA). 2000. Consulta de dades de l'aigua i el medi Xarxes de control del medi. Online resource: http://aca-web.gencat.cat/sdim/visor.do

ACA (AGĖNCIA CATALANA DE L'AIGUA). 2010. Pla de gestió del districte de conca fluvial de Catalunya Annex I - Caracterització de les masses d'aigua superficial naturals. Online resource: http://aca.gencat.cat/web/ .content/30_Plans_i_programes/10_Pla_de gestio/01-1er-cicle-de-planificacio-20092015/bloc1/103_Annex_I_PdG1cicle.pdf

AUKEMA, B., C. RIEGER \& W. RABITSCH. 2013. Catalogue of the Heteroptera of the Palaearctic Region. Volumen 6. Supplement. The Netherlands Entomological Society. Amsterdam. xxiii +629 pp.

BAENA, M. 1980. Heterópteros acuáticos de la Sierra de los Santos y Sierra de Córdoba. Tesis de Licenciatura Universidad de Córdoba. No publicada.

BAENA, M. \& M. Á. VÁZQUEZ. 1986. Catálogo preliminar de los Heterópteros acuáticos ibéricos (Heteroptera: Nepomorpha, Gerromorpha). Graellsia, 42: 61-89.

BARTRAM, J. \& R. BALANCE. 1996. Water Quality Monitoring - A Practical Guide to the Design and the Implementation of Freshwater Quality Studies and Monitoring Programmes, UNEP/WHO.

BRACKEN, J. J. 1974. Notes and observations on distribution of Aphelocheirus aestivalis Fabr. forma montandoni Horv. in Irish waters. Freshwater Biology, 4: 227-232.

BRUGMANS, B., M. MOELEKER, E. WEERMAN \& R. LAPPERRE. 2015. Woody debris increases macroinvertebrates communities in stream construction works. In: Proceedings of the International Conference on River and Stream Restoration "Novel Approaches to Assess and Rehabilitate Modified Rivers". N. Angelopoulos \& T. Buijse (eds.): 232-237. FP7 REFORM deliverable 7.5.

CAÑEDO-ARGÜELLES, M., M. SALA, G. PEIXOTO, N. PRAT, M. FARIA, A. SOARES, C. BARATA \& B. KEFFORD. 2015. Can salinity trigger cascade effects on 
streams? A mesocosm approach. Science of total environment, 540 (1): 3-10.

CARBONELL, J. A., P. ABELLÁN, P. ARRIBAS, J. F. ELDER \& A. MILLÁN. 2011. The genus Aphelocheirus Westwood, 1833 (Hemiptera: Aphelocheiridae) in the Iberian Peninsula. Zootaxa, 2771: 1-16.

CARBONELL, J. A. \& A. MILLÁN. 2010. Aphelocheirus murcius Nieser \& Millán, 1989 y Aphelocheirus occidentalis Nieser \& Millán, 1989 (Hemiptera: Aphelocheiridae) dos hemípteros acuáticos endémicos de la Península Ibérica amenazados. Boletín de la Sociedad Entomológica Aragonesa, 46: $429-435$.

CASADO, C, C. MONTES, D. GARCÍA DE JALÓN \& O. SORIANO. 1990. Contribución al estudio faunístico del bentos fluvial del Rio Lozoya (Sierra de Guadarrama, España). Limnetica, 6: 87-100.

DE BRABANDER, K., G. VANHOOREN \& A. RINGELE. 1992. Comparing biological and chemical parameters as complementary tools for the management of river water quality. In: River water quality ecological assessment and control. P.J. Newman, M.A. Piavaux \& R.A. Sweeting (Eds.) 35-62. Luxembourg: Office for Official Publications of the European Communities.

FERNÁNDEZ BERNALDO DE QUIRÓS, C. 1982. Heterópteros acuáticos y semiacuáticos de Asturias (N. España). I. Catálogo sistemático. Boletín de la Real Sociedad Española de Historia Natural (Biol.), 80: 211-218.

FILIPE, A. F., J. E. LAWRENCE \& N. BONADA. 2013. Vulnerability of stream biota to climate change in Mediterranean climate regions: a synthesis of ecological responses and conservation challenges. Hydrobiologia, 719 (1): 331-351.

FORTUÑO, P., N. BONADA, N. PRAT, R. ACOSTA, M. CAÑEDO-ARGÜELLES, D. CASTRO, N. CID, C. MÚRRIA, D. PINEDA, K. ROCHA, M. SÓRIA, P. TARRATS \& I. VERKAIK. 2018. Efectes del CAnvi Ambiental en les comunitats d'organismes dels RIus MEDiterranis (CARIMED). Informe 2017. Diputació de Barcelona. Àrea d'Espais Naturals (Estudis de la Qualitat
Ecològica dels Rius; 27). 80 pp. online resource: http://www.ub.edu/barcelonarius/ web/index.php/informe-2017 [Accessed 25 March 2019].

GASITH, A. \& V. H. RESH. 1999. Streams in Mediterranean climate regions: abiotic influences and biotic responses to predictable seasonal events. Annual Review of Ecology and Systematics, 51-81.

GIORDANO, P. 2018. Finding of Aphelocheirus aestivalis Fabricius 1794 in the River Chiese, Villanuova sul Clisi (Brescia, Italy). Journal of Life Sciences, 6 (2018): 183-188. DOI: 10.17265/1934-7391/2018.04.003

GÓMEZ MENOR, J. 1956. Las tribus de Hemípteros de España. C.S.I.C. Madrid. 140 p. GOULA, M., J. RIBES \& A. SERRA. 2010. Llistat dels heteròters de Catalunya (Insecta, Hemiptera, Heteroptera). Versió 1, juny 2010. http://www.ub.edu/crba/publicacions/ Llista\%20heteropters/Llista_heteropters_de Catalunya_Versio_1.pdf [Accessed $8 \overline{\text { April }}$ 2019].

GRIJALBO CERVANTES, J. 1991. La laguna de San Juan y demás zonas húmedas del Tajuña. Agencia del Medio Ambiente de la Comunidad de Madrid. Madrid. 265 p.

KANYUKOVA, E. V. 1995. Family Aphelocheiridae Fieber, 1851. In: Aukema, B. \& Rieger, Ch. (Eds), Catalogue of the Heteroptera of the Palearctic Region. Netherland Entomological Society, pp 60-63.

LEMB, M. \& G. MAIER. 1996. Prey selection by the water bug Aphelocheirus aestivalis Fabr. (Heteroptera: Aphelocheiridae). Internationale Revue der Gesamten Hydrobiologie, 81: 481-490.

LINDBERG, H. 1929. Inventa entomologica itineris Hispanici et Maroccani, 1. Hemiptera Heteroptera Hydrobiotica. Commentationes Biologicae, 3 (4): 1-13.

LÓPEZ, T. 1998. Heterópteros acuáticos de la provincia de Madrid. Universidad Complutense de Madrid. Tesis Doctoral. 359 p. https://eprints.ucm.es/4217/1/T22869.pdf. [Accessed 9 April 2019]

LÓPEZ, T., M. COSTAS \& M. Á. VÁZQUEZ. 1995. Nepomorpha y Gerromorpha de la provincia de Madrid. Contribución al conoci- 
miento de la biodiversidad entomológica ibérica (Heteroptera). In: Avances en Entomologia Ibérica. Comité Editorial (eds.). Museo Nacional de Ciencias Naturales (CSIC) y Universidad Autónoma de Madrid.

LUCAS CASTRO, M. T. 1988. Los Nepomorpha y los Gerromorpha Heteroptera de la provincia de León. Excma. Diputación Provincial de León. $322 \mathrm{p}$.

MAES, D., D. BROSENS, F. T'JOLLYN, P. DESMET, F. PIESSCHAERT, S. VAN HOEY, T. ADRIAENS, W. DEKONINCK, K. DEVOS, K. LOCK, T. ONKELINX, J. PACKET, J. SPEYBROECK, A. THOMAES, K. VAN DEN BERGE, W. VAN LANDUYT, H. VERREYCKEN. 2019. Validated red lists of Flanders, Belgium. Version 1.3. Research Institute for Nature and Forest (INBO). Checklist dataset DOI: $10.15468 / 8$ tk3tk accessed via GBIF.org on 2019-04-09.

MESSNER, B., M. HEGEMANN \& M. SCHMIDT. 1986. The chloride cells of the waterbug, Aphelocheirus aestivalis (Heteroptera, Corixidae) and their possible functions as breathing aid in the larvae. Zoologisch Jahrbucher-Abteilung fur Allgemeine Zoologie und Physiologie der Tiere, 90: 13-30.

MIGUÉLEZ, D. \& L. F. VALLADARES. 2010. Fenología de insectos acuáticos en un humedal protegido (Red Natura 2000) del noroeste de España. Limnetica, 29 (2): 387-392.

MILLAN, A., O. L'MOHDI, J. A. CARBONELL, A. F. TAYBI \& M. DAKKI. 2016. A new species of Aphelocheirus (Hemiptera: Heteroptera: Aphelocheiridae) from Morocco. Zootaxa, 4173 (6): 577-582.

MILLÁN, A., J. L. MORENO \& J. VELASCO. 2002. Los Coleópteros y Heterópteros acuáticos y semiacuáticos de la provincia de Albacete. Catálogo faunístico y estudio ecológico. Instituto de Estudios Albacetenses "Don Juan Manuel", Excma. Diputación Provincial de Albacete, Albacete, $180 \mathrm{pp}$.

MUNNÉ A., N. PRAT, C. SOLÁ, N. BONADA \& M. RIERADEVALL. 2003. A simple field method for assessing the ecological quality of riparian habitat in rivers and streams: QBR index. Aquatic Conservation: Marine and
Freshwater Ecosystems, 13 (2): 147-163.

MURILLO, J. 1985. Algunes captures d'Heteròpters aquàtics efectuades a Catalunya $\mathrm{i}$ altres localitats de la resta de la Península Ibérica. Butlletí de la Institució Catalana d'Història Natural, 52 (Sec. Zool.), 6: 139-147.

MÚRRIA, C., N. BONADA, C. RIBERA \& N. PRAT. 2010. Homage to the Virgin of Ecology, or why an aquatic insect unadapted to desiccation may maintain populations in very small, temporary Mediterranean streams. Hydrobiologia, 653 (1): 179-190.

NIESER, N. 1978. Heteroptera. In: Limnofauna Europae. J. Illies (Ed.). Gustav Fisher Verlag. Suttgart. $532 \mathrm{p}$.

NIESER, N., M. BAENA, J. MARTÍNEZ-AVILÉS \& A. MILLÁN. 1994. Claves para la identificación de los heterópteros acuáticos (Nepomorpha \& Gerromorpha) de la Península Ibérica-Con notas sobre las especies de las Islas Azores, Baleares, Canarias y Madeira. Asociación Española de Limnología, Madrid. $112 \mathrm{p}$.

NIESER, N. \& C. MONTES. 1984. Lista faunistica y bibliográfica de los Heterópteros acuáticos (Nepomorpha \& Gerromorpha) de España y Portugal. Listas de la Flora y Fauna de las aguas continentales de la Península Ibérica $n^{\circ} 1$. Asociación Española de Limnología, $69 \mathrm{pp}$.

NIESER, N. \& A. MILLÁN. 1989. Two new species of Aphelocheirus from the Iberian Peninsula (Heteroptera: Naucoridae). Entomologische Berichten, 49: 111-117.

PAPÁČEK, M. 2012. On the benthic water bug Aphelocheirus aestivalis (Fabricius, 1794) (Heteroptera, Aphelocheiridae): Minireview. Entomologica Austriaca, 19: 9-19.

PAPÁČEK, M \& T. SOLDÁN. 2008. Structure and development of the reproductive system in Aphelocheirus aestivalis (Hemiptera: Heteroptera: Nepomorpha: Aphelocheiridae). Acta Entomologica Musei Nationalis Pragae, 48 (2): 299-318.

PARDO, L. 1933. Datos para el estudio de la fauna hidrobiológica española. Boletín de Caza y Pesca, 5(1): 1-15.

PARDO, I., M. ALVAREZ, J. CASA, J. L. 
MORENO, S. VIVAS, N. BONADA, J. ALBA-TERCEDOR, P. JAIMEZ-CUÉLLAR, G. MOYÀ, N. PRAT, S. ROBLES, M. L. SUÁREZ, M. TORO \& M. R. VIDAL-ABARCA. 2004. El hábitat de los ríos mediterráneos. Diseño de un índice de diversidad de habitat. Limnetica, 21:115-134.

PARDO, I., C. GÓMEZ-RODRÍGUEZ, R. ABRAÍN, E. GARCÍA-ROSELLÓ \& T. B. REYNOLDSON. 2014. An invertebrate predictive model (NORTI) for streams and rivers: Sensitivity of the model in detecting stress gradients. Ecological Indicators, 45: 51-62.

POLHEMUS, J. T. \& D. A. POLHEMUS. 2008. Global diversity of true bugs (Heteroptera; Insecta) in freshwater. Hydrobiologia, 595: 379-391.

PRAT, N., P. FORTUÑO, M. RIERADEVALL, R. ACOSTA, N. BONADA, D. CASTRO, M. CAÑEDO-ARGÜELLES, N. CID, C. MÚRRIA, P. RODRÍGUEZ-LOZANO, N. SÁNCHEZ \& P. TARRATS. 2016. Efectes del CAnvi Ambiental en les comunitats d'organismes dels RIus MEDiterranis (CARIMED). Informe 2015. Diputació de Barcelona. Àrea d'Espais Naturals (Estudis de la Qualitat Ecològica dels Rius; 25). online resource: http://www.ub.edu/barcelonarius/web/index. php/informe-2015.

PRAT, N. \& A. MUNNÉ. 2000. Water use and quality and stream flow in a Mediterranean stream. Water Research, 34 (15): 3876-3881.

PRAT, N. \& M. RIERADEVALL. 2006. 25-years of biomonitoring in two mediterranean streams (Llobregat and Besòs, basins, NE Spain). Limnetica, 25 (1-2): 541-550.

PRAT, N., M. RIERADEVALL \& P. FORTUÑO. 2012. Metodología F.E.M. para la evaluación del estado ecológico de los ríos Mediterráneos. F.E.M. Research Group (Freshwater Ecology and Management), Department of Ecology, University of Barcelona. Online resource: http://www.ub.edu/fem/ docs/protocols/fem_\%20prot_cast_2012.pdf

RIBES, J., A. SERRA \& M. GOULLA. 2004. Catàleg dels Heteròpters de Catalunya (Insecta, Hemiptera, Heteroptera). Institució Catalana d'Història Natural i Institut d'Es- tudis Catalans. Barcelona. $125 \mathrm{p}$.

RIBES, J., M. GOULA, S. PAGOLA-CARTE, F. GESSÉ \& E. RIBES. 2008. Addicions i correccions al catàleg dels Heteròpters de Catalunya (Insecta, Hemiptera, Heteroptera). Sessió Entomologia ICHN-SCL, 13-14: 107-165.

SÁNCHEZ-FERNÁNDEZ, D., D. T. BILTON, P. ABELLÁN, I. RIBERA \& A. MILLÁN. 2008. Are the endemic water beetles of the Iberian Peninsula and the Balearic Islands effectively protected? Biological Conservation, 141: 1612-1627.

SÁNCHEZ-HERNÁNDEZ， J. 2011. Características biológicas y ecológicas de los macroinvertebrados en un sector del hiporitron en el río Tormes (España Central). Zoologia baetica, 22: 51-67.

SÁNCHEZ-HERNÁNDEZ, J. \& F. COBO. 2011. Summer food resource partitioning between four sympatric fish species in Central Spain (River Tormes). Folia Zoologica, 60 (3): 189-202.

SEABRA, A. F. DE 1926. Hemiptères Hétéroptères de la province de Tras-os-Montes. Memórias e Estudos do Museu Zoológico da Universidade de Coimbra, Ser. 1, 8: 5-39.

SEABRA, A. F. DE 1939. Contribução para a história da entomologia em Portugal. Publicações da Direcção Geral dos Serviços Florestais e Aqüicolas, 6 (2): 155-302.

SEABRA, A. F. DE 1941. Contribuçoes para o inventário da fauna lusitânica. Insecta. Heteroptera. Memórias e Estudos do Museu Zoológico da Universidade de Coimbra, 1 (123): 1-37.

SERRÃO, C. D. \& F. AZEVEDO. 1970. Insectos do agua doce da fauna lusitânica (Revisão bibliográfica). Estudos e divulgação técnica. Secção Aquicultura. Secretaria do Estado da Agricultura. Direcâo Geral dos servicos forestais e aguicolas. Avalade, Lisboa: J.F. Miranda Lisboa. 34 p.

STOIANOVA, D., V. EVTIMOVA, L. KENDEROV, E. D. VARADINOVA, M. Y. KERAKOVA, M. K. IHTIMANSKA \& N. SIMOV. 2018. New localities and habitat suitability modelling for the riverine water bug Aphelocheirus aestivalis (Fabricius, 1794) (Heteroptera: Aphelocheiridae) in 
Northern and Eastern Bulgaria. Acta Zoologica Bulgarica, 70(3): 415-431.

THORPE, W. H. \& D. J. CRISP. 1947a. Studies on plastron respiration 1. The biology of Aphelocheirus [Hemiptera, Aphelocheiridae (Naucoridae)] and the mechanism of plastron retention. Journal of Experimental Biology, 24: $227-269$.

THORPE, W. H. \& D. J. CRISP. 1947b. Studies on plastron respiration 2 . The respiratory efficiency of the plastron in Aphelocheirus. Journal of Experimental Biology, 24: 270-303.

THORPE, W. H. \& D. J. CRISP. 1947c. Studies on plastron respiration 3. The orientation responses of Aphelocheirus [Hemiptera, Aphelocheiridae (Naucoridae)] in relation to plastron respiration- together with an account of specialized pressure receptors in aquatic insects. Journal of Experimental Biology, 24: 310-328.

THORPE, W. H. 1950. Plastron respiration in aquatic insects. Biological Reviews, 25 (3): 344-390.

XIE, T. \& G. Q. LIU. 2014. Two new species and three new records of the genus Aphelocheirus (Hemiptera: Heteroptera: Aphelocheiridae) from China. Zootaxa, 3793 (2): 222-230.

ŽIVIĆ, I., L. PROTIĆ \& Z. MARKOVIĆ. 2007. Southernmost finding in Europe of Aphelocheirus aestivalis (Fabricius, 1794) (Hemiptera: Heteroptera: Aphelocheiridae). Zootaxa, 1496: 63-68. 